\title{
Occupational Injuries among Dentists in Croatia
}

\section{Ozljede na radu među stomatolozima u Hrvatskoj}

\author{
${ }^{1}$ University of Zagreb, School of Dental Medicine, Department of Dental Anthropology, Zagreb, Croatia \\ Zavod za dentalnu antropologiju Stomatološkog fakulteta Sveučilišta u Zagrebu, Hrvatska \\ 2 Private dental office, Croatia \\ Stomatološka ordinacija Zagreb, Hrvatska \\ ${ }^{3}$ FAMA College, Pristina, Kosovo \\ Sveučilište FAMA, Priština, Kosovo \\ ${ }^{4}$ Ministry of Health, Pristina, Kosovo \\ Ministarstvo zdravstva Kosova, Priština, Kosovo \\ ${ }^{5}$ University Hospital Centre Zagreb, Zagreb, Croatia \\ Klinika za stomatologiju Kliničkoga bolničkog centra Zagreb, Hrvatska
}

\section{Abstract}

Objectives: Dental profession is characterized by a high risk of injuries at work due to exposure to specific working conditions. The operating area in a patient's mouth is small, and it is handled by a large number of sharp instruments and drills that rotate at high speed, which creates an aerosol contaminated with particles of saliva and blood. This poses a risk of transmitting infections from patients to the dentist through stabbing incidents and cuts, which are some of the most common occupational injuries that are reported in the scientific literature. Objective: The aim of this study was to examine the frequency of occupational injuries among dentists in Croatia, to establish most common injuries, and to determine the main risk factors. The aim of this research was also to determine the dentists' opinion on causes that are responsible for the occupational diseases and injuries. Material and methods: The survey was conducted based on a sample of 406 dentists from Croatia as respondents to an electronic survey. Results: $63.05 \%$ of the respondents suffered injuries caused by dental practitioners. The most common injuries were needle puncture incidents $(57.75 \%)$ and cuts $(20.86 \%)$, followed by eye injuries $(13.37 \%)$, patient bite $(4.81 \%)$ and punches $(1.60 \%)$. The largest number of respondents stated the improper posture as the most important cause of occupational diseases and injuries, followed by stress, infection and noise. Conclusion: Knowledge of risk factors is the first step of injury prevention. Our respondents were largely aware of the dangers surrounding them. Nevertheless, the frequency of injuries was high and there is still a need for preventive measures to minimize the frequency of injuries in dentistry.
Received: January 15, 2020

Accepted: March 1, 2020

Address for correspondence Ivana Savić Pavičin

University of Zagreb

School of Dental Medicine

Department of Dental Anthropology Gundulićeva 5, 10000 Zagreb savic@sfzg.hr

Key words

Occupational Injuries; Dentists; Croatia; Risk Factors

\section{Introduction}

The dental profession is rated worldwide as a high-risk profession by many parameters (1).

Research shows that dentists have a distinct tendency for occupational diseases, work-related illnesses and, unfortunately, a high risk of injury during work $(2,3)$.

Occupational diseases and injuries at work have multiple etiologies, and specific working conditions are one of the important factors $(4,5)$. The cause of the disease is usually longterm exposure and a high concentration of specific harmful and adverse substances, various microorganisms, and repeated forced non-physiological positions of the body (5). The tendency toward incurring work-related injuries results from constant handling of a large number of sharp instruments and needles, a small working area and the flow of air and water which, in addition to the saliva and blood of the patient, can cause injury to the eye by foreign objects (tooth splinters, material, etc.).
Uvod

Stomatološka profesija procijenjena je u svijetu kao visoko rizična i to prema mnogim parametrima (1).

Istraživanja pokazuju da su stomatolozi skloni profesionalnim bolestima, bolestima povezanima $s$ radom te da su, nažalost, često u opasnosti od ozljeda tijekom rada $(2,3)$.

Profesionalne bolesti i ozljede na radu imaju višestruku etiologiju, a specifični radni uvjeti jedan su od bitnih čimbenika $(4,5)$. Uzroci obolijevanja najčešće su dugotrajna izloženost i visoka koncentracija specifičnih štetnih i nepovoljnih tvari, različitih mikroorganizama te opetovani prisilni nefiziološki položaj tijela (5). Sklonost ozljedama na radu povećava i stalno rukovanje velikim brojem oštrih instrumenata i igala, malo radno polje te strujanje zraka i vode što, uz slinu i krv pacijenta, može uzrokovati ozljedu oka stranim tijelima (krhotine zuba, materijala i sl.).

Rizične čimbenike u stomatološkoj profesiji možemo podijeliti na biološke, biomehaničke, kemijske, fizikalne i psi- 
Risk factors in the dental profession can be divided into biological, biomechanical, chemical, physical and psychogenic (5).

Biological factors include viruses, fungi, bacteria and prions that dentists encounter through direct labor in the patient's mouth, due to exposure to saliva, which in many cases is contaminated with the patient's blood. Dentists' awareness of the risks of transmission of infections, primarily hepatitis and HIV, is a necessary prerequisite for prevention, combined with the mandatory use of protective equipment $(1,5)$.

Biomechanical risk factors include involuntary improper posture and repeated movements, body overstimulation affecting the musculoskeletal and / or neurological system (1).

The term chemical risk factors include various medicines and dental materials that can cause chemical injury, as well as protective equipment and disinfectants that, cumulatively, could be potential allergens with a potential toxic effect $(1,5)$.

Physical factors are factors that can lead to hearing and vision disorders such as radiation, noise, vibration, artificial lighting, and polymerization light (5).

Psychogenic factors include high levels of daily stress, chronic fatigue and burnout syndrome at work. As a result, various psychosomatic diseases can occur. Also, mental and physical fatigue can lead to decreased concentration and careless behavior while working, which increases the risk of stabbing and other injuries (6).

Due to the specific working conditions and a large number of sharp instruments and needles used by dentists in their work, stabbing incidents are possible and unfortunately occur during clinical work. Apart from the mechanical injury itself, a much bigger problem is the possibility of transmission of the infections and diseases from patients to dentists, if the patient is ill or infected with HIV or hepatitis B and C.

It is estimated that around 257 million people worldwide are chronically infected with hepatitis B and 71 million people with hepatitis C. Croatia is one of the countries with a low rate of hepatitis, but it still poses a high risk for dentists, given that about 25,000 people in Croatia are chronically infected with hepatitis B virus and 40,000 hepatitis $C$ virus (7).

In Croatia, between 1985 and the end of 2018, there were 1,640 people diagnosed as HIV positive (8). The overall number is not large, but it is not a negligible risk when it comes to possible transmission of infection in dental work.

In order to take a serious approach to the problem and to ensure adequate preventive action, Croatian dentists need to study risk factors and the current situation. As we have not found data on occupational injuries within the dental profession in Croatia in the recent literature, we decided to carry out a survey and collect data on the most common injuries as well as data on the awareness of dentists about the health risks present in the workplace.

The purpose of this paper was to investigate into the frequency of occupational injuries among dentists in Croatia, the injuries which occur most frequently to dentists during work, and to identify the risk factors that may be associated with a higher incidence of injuries (gender, age, specialization, and years of practice). One of the goals of the research was to determine the opinion of the dentist about the con- hogene (5).

U biološke čimbenike ubrajamo viruse, gliivice, bakterije i prione koji stomatolozima prijete zbog izravnog rada u pacijentovim ustima i izloženosti slini koja je često kontaminirana krvlju pacijenta. Svjesnost stomatologa o rizicima u slučaju prijenosa infekcija, ponajprije hepatitisa i HIV-a, nužan je preduvjet u prevenciji, uz obveznu upotrebu zaštitne opreme $(1,5)$.

Biomehanički rizični čimbenici su prisilan nepravilan položaj tijela i opetovane kretnje te prenaprezanje tijela, što pogađa mišićno-koštani i/ili neurološki sustav (1).

Rizičnih kemijski čimbenici su različiti lijekovi i stomatološki materijali koji mogu uzrokovati kemijske ozljede te zaštitna oprema i dezinficijensi zato što mogu, u kumulativnom smislu, biti alergeni s toksičnim učinkom $(1,5)$.

Fizikalni čimbenici su oni koji svojim djelovanjem mogu potaknuti poremećaje sluha i vida, kao što su, na primjer, zračenje, buka, vibracije, umjetna rasvjeta, polimerizacijsko svjetlo itd (5).

U psihogene čimbenike ubrajamo visoku razinu svakodnevnog stresa, kronični umor i sindrom izgaranja na poslu. Posljedično se mogu pojaviti različite psihosomatske bolesti. Psihički i fizički umor također mogu smanjiti koncentraciju i potaknuti neoprezno ponašanje tijekom rada, što povećava rizik od ubodnih i drugih ozljeda (6).

Zbog specifičnih radnih uvjeta te mnogobrojnih oštrih instrumenata i igala kojima rukuju stomatolozi, ubodni su incidenti mogući i, nažalost, događaju se u kliničkom radu. Osim same mehaničke ozljede, mnogo je veći problem eventualni prijenos infekcije $s$ pacijenta na stomatologa, ako pacijent boluje ili je zaražen virusom HIV-a ili hepatitisa B i C.

Procjenjuje se da je oko 257 milijuna ljudi u svijetu kronično zaraženo hepatitisom $\mathrm{B}$, a 71 milijun hepatitisom $\mathrm{C}$. Hrvatska je među zemljama s niskom učestalošću hepatitisa, ali ta bolest i dalje je velik rizik za stomatologe, s obzirom na to da je oko 25000 osoba u našoj zemlji kronično zaraženo virusom hepatitisa B i 40000 virusom hepatitisa C (7).

U Hrvatskoj je u razdoblju od 1985. do kraja 2018. zabilježeno 1640 bolesnika kojima je dijagnosticirana infekcija HIV-om (8). Sveukupan broj nije velik, ali ipak nije zanemariv rizik kad govorimo o mogućem prijenosu infekcije u stomatološkom radu.

Kako bi se ozbiljno pristupilo problemu i osiguralo odgovarajuće preventivno djelovanje, najvažnije je proučiti rizične čimbenike i trenutačno stanje među hrvatskim stomatolozima. Budući da u recentnoj literaturi nismo pronašli podatke o ozljedama na radu unutar stomatološke profesije u Hrvatskoj, odlučili smo provesti istraživanje i prikupiti podatke o najčešćim ozljedama i svjesnosti stomatologa o zdravstvenim rizicima na njihovu radnom mjestu.

Svrha ovoga rada bila je istražiti učestalost ozljeda hrvatskih stomatologa na radu i koje su najčešće, te utvrditi rizične čimbenike koje možemo povezati s njihovom češćom pojavom (spol, dob, specijalizacija, godine staža). Jedan od ciljeva istraživanja bio je i ustanoviti što stomatolozi misle o uzročnicima odgovornima za nastanak profesionalnih bolesti i ozljeda na radu. 
tributing factors responsible for the occurrence of occupational diseases.

\section{Material and methods}

The research was conducted through electronic survey, which was sent via email to 800 addresses of actively working dentists in the Republic of Croatia. Participation in the survey was anonymous and voluntary and all respondents had been in the dental profession for at least one year. The questionnaire consisted of three parts; demographics included gender, age, length of service and specialization. The second part was about the dentist's awareness of occupational health risks. The third part deals with previous experience of workplace injuries in dental offices.

The study was approved by the Ethics Committee of the School of Dental Medicine in Zagreb.

Statistical analysis was performed using the Statistica computer program (TIBCO Software Inc, Palo Alto, CA, USA). A chi-square test was used to analyze the data obtained in order to determine a statistically significant difference in the frequency of the tested parameters between multiple groups, with a statistical significance level of $\mathrm{p}<0.05$.

\section{Results}

Out of 800 dentists surveyed, 406 dentists completed and answered the questionnaire; the response rate was $50.8 \%$. Out of the total number of respondents, $39.16 \%$ were men and $60.84 \%$ were women.

The distribution of respondents by age and years of practice is shown in Figure 1. Most of the respondents were general dental practitioners (69.88\%); however, all specialist branches were covered by the answers (Figure 2).

$33.25 \%$ of the respondents with infections believed that they were related to the workplace, while $14.70 \%$ of the respondents requested medical intervention because of this. A statistically significant correlation was found between infections (for which the respondents believed were related to dental practice $)$ with age $\left(\mathrm{p}<0.05, \chi^{2}=11.84, \mathrm{df}=3\right)$ and years of practice $\left(p<0.05, \chi^{2}=8.99, \mathrm{df}=3\right)$, the number of reported infections increased with age. There were no significant associations with other parameters such as gender and specialization. The number of subjects who sought medical attention for such an infection was not associated with any of the parameters examined. $63.05 \%$ of the respondents suffered injuries caused by dental practice and $16.5 \%$ sought the help of a doctor because of this injury. The incidence of injuries was almost the same in men (61.64\%) and in women (63.97\%), while female respondents were significantly more likely to seek medical attention after injury $\left(\mathrm{p}<0.05, \chi^{2}=3.89\right.$, $\mathrm{df}=1$ ). Out of other parameters examined, seeking medical assistance after injury was only related to years of practice $\left(\mathrm{p}<0.05, \chi^{2}=10.01, \mathrm{df}=3\right)$.

The most common injuries were needle puncture incidents $(57.75 \%)$ and cuts $(20.86 \%)$, followed by eye injuries $(13.37 \%)$, patient bite $(4.81 \%)$ and hit by the patient $(1.60 \%)$. The needle puncture incident did not show a signif-

\section{Ispitanici i metode}

Istraživanje je provedeno elektronički, anketom poslanom na 800 adresa stomatologa koji obavljaju djelatnost na području Republike Hrvatske. Sudjelovanje je bilo anonimno i dobrovoljno, a svi ispitanici obavljali su stomatološku djelatnost najmanje godinu dana. Upitnik se sastojao od triju dijelova. U prvom dijelu tražili su se demografski podatci - o spolu i dobi, te duljini radnog staža i specijalizacije. Drugi dio odnosio se na osviještenost stomatologa kad je riječ o profesionalnim zdravstvenim rizicima. $U$ trećem dijelu odgovarali su na pitanja o dosadašnjim iskustvima s ozljedama na radu u svojim ordinacijama.

Istraživanje je odobrilo Etičko povjerenstvo Stomatološkog fakulteta u Zagrebu.

Statistička analiza obavljena je računalnim programom Statistica (TIBCO Software Inc, Palo Alto, CA, SAD). Za analizu dobivenih podataka korišten je hi-kvadrat test u svrhu utvrđivanja statistički značajne razlike u učestalosti ispitivanog svojstva između više skupina, uz razinu statističke značajnosti $\mathrm{p}<0,05$.

\section{Rezultati}

Anketa je poslana na 800 adresa, a upitnik je ispunilo i odgovorilo na postavljena pitanja 406 stomatologa. Dakle, stopa sudjelovanja bila je 50,8\%. Od ukupnog broja ispitanika 39,16 \% bili su muškarci, a 60,84 \% žene.

Distribucija ispitanika, $s$ obzirom na radni staž i godine, nalazi se na slici 1 . Među ispitanicima uglavnom su bili zastupljeni opći stomatolozi $(69,88 \%)$, no odgovorima su bile obuhvaćene sve specijalističke grane (slika 2).

Infekcije za koje smatra da su bile povezane s radnim mjestom navelo je 33,25 \% ispitanika te je njih 14,70 \% zatražilo liječničku pomoć. Statistički značajna povezanost pokazala se između infekcije (za koju su ispitanici smatrali da je povezana $s$ obavljanjem njihove djelatnosti), dobi $\left(\mathrm{p}<0,05, \chi^{2}=\right.$ $11,84, \mathrm{df}=3)$ i radnoga staža $\left(\mathrm{p}<0,05, \chi^{2}=8,99, \mathrm{df}=3\right)$. Broj prijavljenih infekcija rastao je $s$ dobi ispitanika. $S$ ostalim parametrima, kao što su spol i specijalizacija, nije bilo značajne povezanosti. Broj ispitanika koji je zbog infekcije potražio liječničku pomoć nije bio povezan ni s jednim od ispitivanih parametara. Ozljedu koja je nastala tijekom obavljanja stomatološke djelatnosti navelo je 63,05 \% ispitanika, a 16,5 $\%$ zbog toga je potražilo pomoć liječnika. Učestalosti ozljeda kod muškaraca $(61,64 \%)$ i žena $(63,97 \%)$ bila je gotovo podjednaka, no ispitanice su znatno češće potražile liječničku pomoć nakon ozljede $\left(\mathrm{p}<0,05, \chi^{2}=3,89, \mathrm{df}=1\right)$. Od ostalih ispitivanih parametara traženje liječničke pomoći nakon ozljede bilo je povezano samo $s$ duljinom radnoga staža $(\mathrm{p}<$ $\left.0,05, \chi^{2}=10,01, \mathrm{df}=3\right)$. Ubodni incidenti iglom $(57,75 \%) \mathrm{i}$ porezotine $(20,6 \%)$ bili su najzastupljeniji među ozljedama, a slijede ozljede oka (13,37\%), ugriz pacijenta $(4,81 \%)$ te udarac $(1,60 \%)$. Ubodni incident iglom nije pokazao značajniju povezanost sa spolom, dobi, specijalizacijom i duljinom radnog staža, a porezotine su bile statistički znatno povezane 


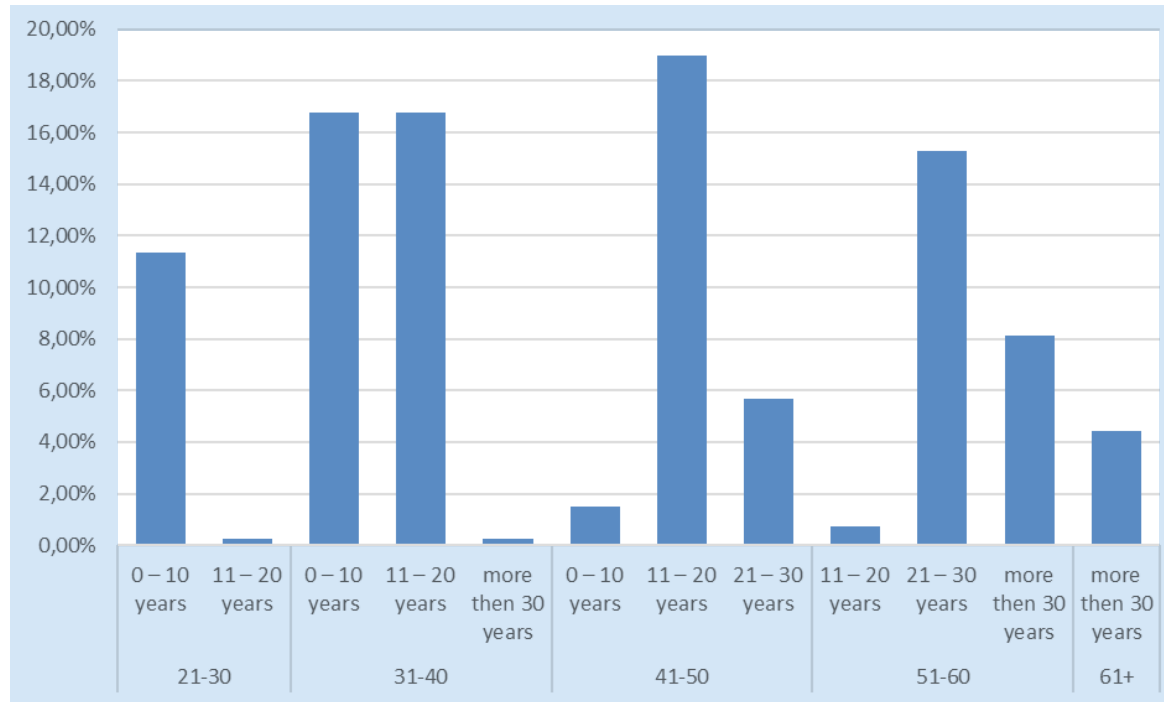

Figure 1 Distribution of respondents by work experience and age (years)

Slika 1. Distribucija ispitanika prema dobi i radnom iskustvu (godine)

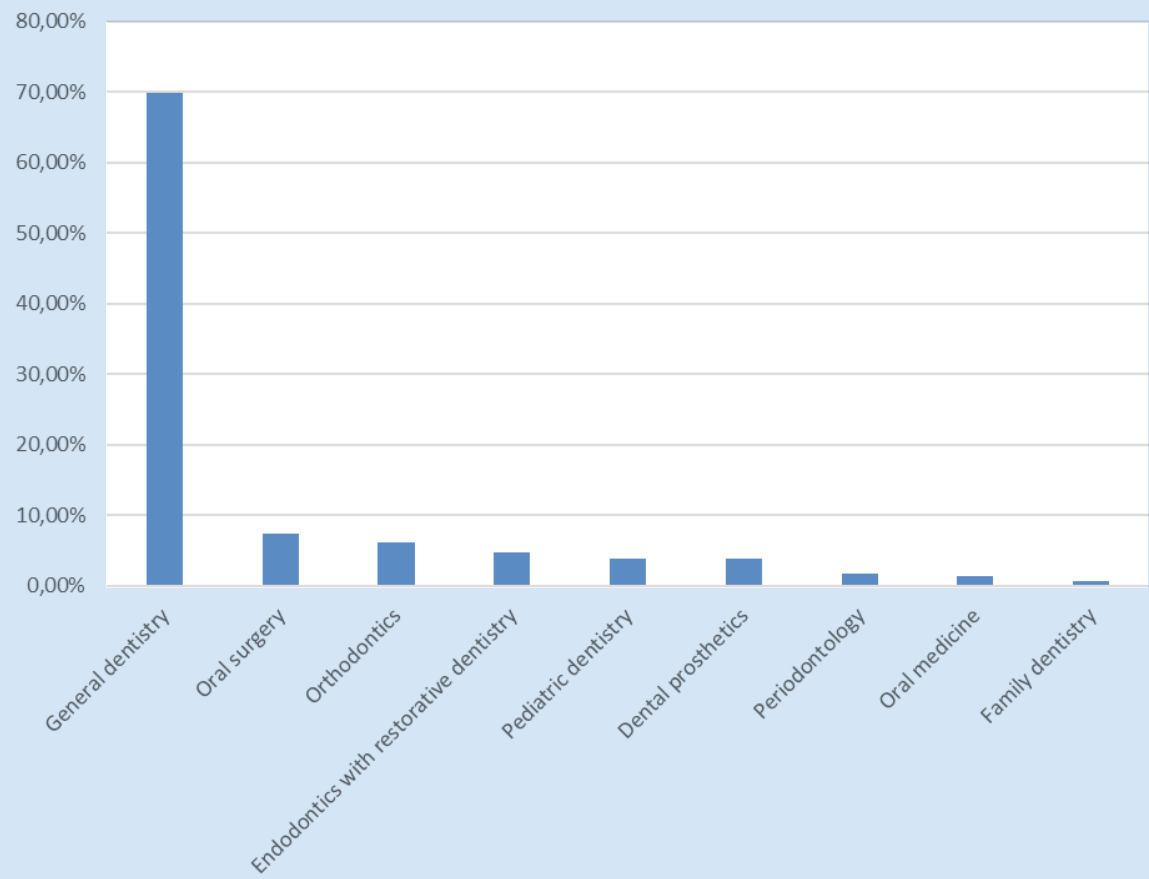

Figure 2 Distribution of respondents by specialization

Slika 2. Distribucija ispitanika prema specijalizaciji

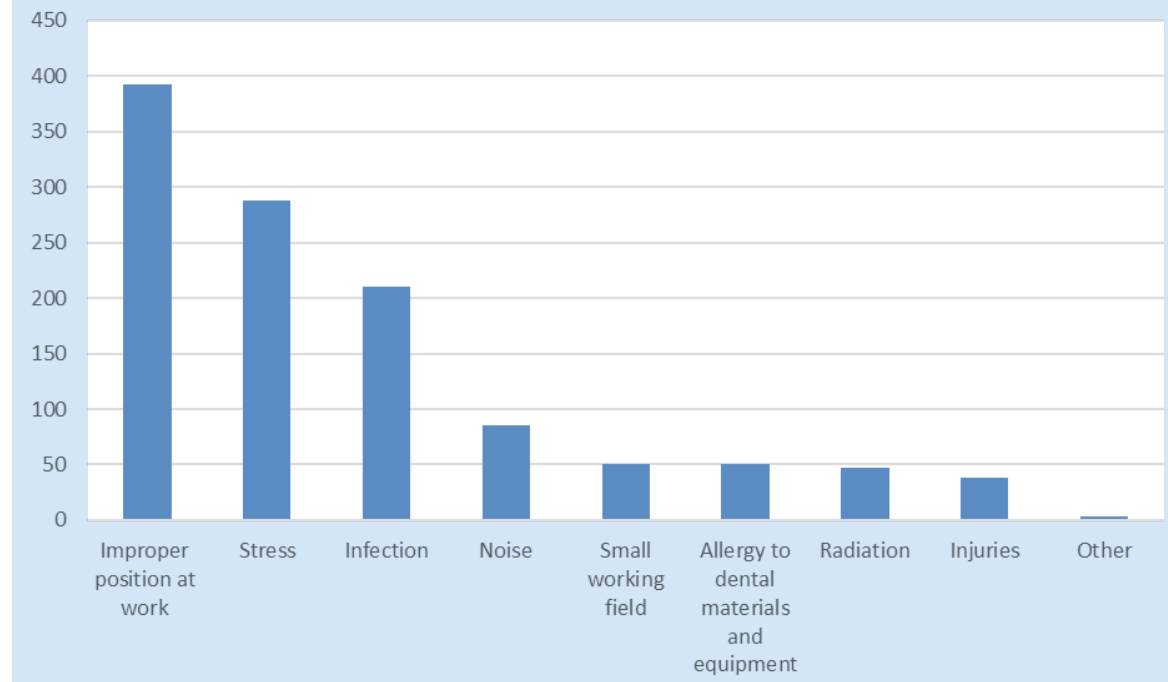

Figure 3 Graphic representations of respondents' opinions on the most important contributing factors responsible for the occurrence of occupational diseases

Slika 3. Grafički prikaz mišljenja ispitanika o najvažnijim uzročnicima profesionalnih bolesti i bolestima vezanima uz rad 
icant association with gender, age, specialization, and length of practice, while the cuts were statistically significantly related to gender only, more commonly occurring in men. Eye injuries were found to be statistically significantly related to the age of the subjects $\left(\mathrm{p}<0.05, \chi^{2}=14.01, \mathrm{df}=3\right)$, most commonly occurring in the age group between 41 and 50 years and $11-$ 20 years of practice $\left(\mathrm{p}<0.05, \chi^{2}=8.71, \mathrm{df}=3\right)$. The bite was reported by 8 respondents and the hit by one respondent. It was not possible to establish a statistical correlation with tested parameters because of a small number of cases. One respondent reported a fall that caused damage to the cervical spine. A stabbing incident in the treatment of patients infected with HIV and / or hepatitis was reported by three respondents.

The respondents' opinion on the most important causes of occupational diseases and diseases related to work is shown in Figure 3.

The largest number of respondents considered incorrect working posture the most important cause of occupational diseases and injuries $(\mathrm{N}=393)$. Gender, age, length of practice and specialization did not significantly affect the responses. Stress was recognized as second most common risk factor $(\mathrm{N}=288)$; tested parameters had no significant effect on the frequency of this response. In the third place, the respondents reported infections $(\mathrm{N}=210)$ and in the fourth they reported noise $(\mathrm{N}=85)$ as the causative agent of occupational diseases and injuries at work. The frequency of selection of infection as the main cause of disease and injury was not influenced by the parameters studied, while noise was statistically significantly more frequently reported by women $(\mathrm{p}<0.05$, chisquare $=5.39, \mathrm{df}=1)$ and subjects in the older age groups $(\mathrm{p}<0.05$. chi-square $=9.73, \mathrm{df}=3)$.

Also, the respondents who were general dentists were more likely to report noise as the causative agent compared to specialists $\left(\mathrm{p}<0.05, \chi^{2}=4.02, \mathrm{df}=1\right)$. Likewise, $\mathrm{X}$-rays were more often considered a risk factor by general dentists $(\mathrm{N}=38)$ compared to specialists $(\mathrm{N}=9)$, however, due to the small number of specialists, statistical significance could not be established. None of the parameters tested had a significant impact on the selection of the small work field and allergy as the cause of disease and injury.

\section{Discussion}

406 dentists participated in this research, representing $8.01 \%$ of the 5066 currently active dentists in Croatia (9).

The choice of dentistry as a profession involves a great risk for development of occupational diseases, diseases related to work and injuries at work, which is confirmed by the results of our research, along with data from previously published research on the health status of dentists in our country (1).

The most commonly reported injuries among the respondents were related to stab incidents, which was also expected and confirmed in similar studies in other countries (10). In our study, more than $78 \%$ out of the total of the respondents had a stabbing incident and other percutaneous injuries.

After Croatia's accession to the European Union, the obligation to report every stabbing incident to the Croatian In- samo sa spolom i češće su se događale muškarcima. Ozljede oka statistički su bile značajno povezane $s$ dobi ispitanika ( $<0,05 \cdot \chi^{2}=14.01, \mathrm{df}=3$ ) i najčešće su se događale u dobnoj skupini između 41 i 50 godina te 11 i 20 godina radnog staža $\left(\mathrm{p}<0,05, \chi^{2}=8,71, \mathrm{df}=3\right)$. Ugriz je prijavilo 8 ispitanika, a udarac jedan. Zbog malog broja takvih slučajeva nije se mogla ustanoviti statistička povezanost $s$ ispitivanim parametrima. Jedan ispitanik naveo je pad koji je uzrokovao oštećenje vratne kralježnice. Ubodni incident pri radu s pacijentima zaraženima HIV-om i/ili hepatitisom navelo je troje ispitanika.

Mišljenje ispitanika o najvažnijim uzročnicima profesionalnih bolesti i bolesti povezanih $s$ radom prikazuje slika 3 .

Najveći broj ispitanika smatrao je da je nepravilan položaj tijela pri radu najvažniji uzročnik profesionalnih bolesti i ozljeda ( $\mathrm{N}=393)$. Pritom spol, dob, duljina radnog staža i specijalizacija nisu statistički značajno utjecali na odgovore ispitanika. Na drugom mjestu je stres $(\mathrm{N}=288)$ - na učestalost tog odgovora ispitivani parametri također nisu značajnije utjecali. Na trećem mjestu ispitanici su naveli infekcije (N = 210), a na četvrtom buku $(\mathrm{N}=85)$. Na učestalost odabira infekcije kao glavnog uzročnika bolesti i ozljeda, nisu utjecali ispitivani parametri, a buku su statistički znatno češće navodile žene $\left(\mathrm{p}<0,05, \chi^{2}=5,39, \mathrm{df}=1\right)$ te ispitanici u starijim dobnim skupinama $\left(\mathrm{p}<0,05, \chi^{2}=9,73, \mathrm{df}=3\right)$. Opći stomatolozi također su češće navodili buku kao uzročnik u usporedbi sa specijalistima $\left(\mathrm{p}<0,05, \chi^{2}=4,02, \mathrm{df}=1\right)$. I rendgensko zračenje češće su smatrali rizičnim čimbenikom opći stomatolozi $(\mathrm{N}=38)$ negoli specijalisti $(\mathrm{N}=9)$, no zbog ma$\log$ broja specijalista ne može se utvrditi statistička značajnost. Na odabir malog radnog polja i na alergije kao uzročnike bolesti i ozljede, ni jedan od ispitivanih parametara nije imao značajan utjecaj.

\section{Rasprava}

U ovom istraživanju sudjelovalo je 406 stomatologa, što je 8,01\% od 5066 danas aktivnih stomatologa u Hrvatskoj (9).

Stomatologija kao profesija uključuje velik rizik od razvoja profesionalnih bolesti, bolesti vezanih uz rad te ozljeda na radu što, uz podatke iz ranije objavljenog rada o zdravstvenom stanju stomatologa u našoj zemlji, potvrđuju i rezultati našeg istraživanja (1).

Najčešće prijavljene ozljede među ispitanicima odnosile su se na ubodne incidente, što je također očekivano i potvrđeno u sličnim istraživanjima u drugim zemljama (10). U našem istraživanju ubodni incident i druge perkutane ozljede navelo je više od $78 \%$ ispitanika.

Nakon ulaska Hrvatske u Europsku uniju jasno je propisano da se svaki ubodni incident mora prijaviti Hrvatsko- 
stitute for Occupational Health and Safety has been clearly stipulated. In 2018, 827 injuries with sharp objects and other exposure incidents were reported, among healthcare professionals in total (11). This number is not large, but the problem is that, unfortunately, many incidents are still not being reported, due to negligence or ignorance of its importance. There are reports that only $5 \%$ to $25 \%$ of exposure incidents are reported in Croatia because of the fear of stigmatization, concerns about data confidentiality, i.e. serological testing findings, and the assumption that the application process is time consuming (12). A stabbing incident by itself does not usually constitute significant tissue damage. Its importance is primarily related to the possibility of transmission of the infection during the injection, after the use of a needle or sharp instrument in patients infected with hepatitis $\mathrm{B}$ or $\mathrm{C}$ virus, and HIV. The risk of transmission of infection after needlestick infection used in an infected patient is $22-31 \%$ for hepatitis $B(12)$. Due to the systematic and very thorough implementation of the vaccination program, the diseases covered by the vaccination program show a very low incidence. The primary focus here is hepatitis $\mathrm{B}$, since no vaccination prophylaxis is available for hepatitis $\mathrm{C}$ and HIV.

Croatia is listed as a country with a low rate of hepatitis $B$, which has been declining for the past twenty years because of the introduction of vaccination. However, hepatitis $\mathrm{B}$ remains a major public health problem, given that about 25,000 people in Croatia are infected with this virus $(2,7)$.

Since 1999, hepatitis B vaccination has been introduced into the compulsory vaccination calendar and children are vaccinated at the age of 12 ( $6^{\text {th }}$ grade of primary school). During this period, it was also mandatory to vaccinate individuals at increased risk for infection (i.e. healthcare professionals, hemodialysis persons, intravenous drug users, home contacts of chronic patients, newborns of $\mathrm{HBsAg}$ positive mothers). Subsequently, hepatitis B vaccination has been introduced into the vaccination program for newborns since 2007 (13).

In regard to HIV transmission, Croatia's accession to the EU has led to faster population migration. Consequently, the risk of potential contagion is greater. In the results of our study, one stabbing incident occurred with a needle while working with an HIV-positive patient. The dentist subsequently underwent post-exposure prophylaxis for a month. The risk of transmission of infection after a percutaneous dental injury if the patient was infected with HIV is about $0.3 \%$, and the possible side effects of post-exposure prophylaxis are not negligible (12).

In a survey of reported percutaneous injuries among health care professionals in Washington State, over a sevenyear period, $20 \%$ of complaints were made by dental professionals. Out of a total of 894 percutaneous injuries, 8 were associated with the patients who were positive for HBV, 30 positive for $\mathrm{HCV}, 3$ positive for HIV and 2 for $\mathrm{HBV}$ and HCV (14).

The survey in Lithuania included 2235 general dentists (15). Over $95.3 \%$ of dentists expressed concern about the potential risk of cross-infection with a patient. HBV immunization was present in $35.9 \%$ of dentists. Hepatitis infec- me zavodu za zaštitu zdravlja i sigurnost na radu. Tijekom 2018. ukupno je prijavljeno 827 ozljeda oštrim predmetima i ostalih ekspozicijskih incidenata (11). Taj broj nije velik, ali problem je činjenica da se, nažalost, još uvijek mnogo incidenata ne prijavljuje jer se umanjuje njihovo značenje zbog nemara ili neznanja. Prema dostupnim podatcima u Hrvatskoj se prijavljuje između 5 i $25 \%$ ekspozicijskih incidenata, a kao razlozi za neprijavljivanje najčešće se navode strah od stigmatizacije, zabrinutost za povjerljivost podataka, tj. nalaza seroloških testiranja, te stajališste da postupak prijave oduzima mnogo vremena (12). Ubodni incident, inače, najčešćc tkivo ne oštećuje znatno. Opasan je uglavnom zbog mogućeg prijenosa infekcije pri ubodu, nakon korištenja igle ili oštrog instrumenta ako je pacijent bio zaražen virusom hepatitisa $B$ ili C, ili HIV-om. Rizik od prijenosa infekcije nakon uboda iglom korištenom u liječenju zaraženog pacijenta iznosi 22 do $31 \%$ za hepatitis B (12). U populaciji građana $\mathrm{RH}$, zahvaljujući sustavnoj, vrlo temeljitoj provedbi cijepljenja, bolesti koje su obuhvaćene tim programom vrlo su rijetke. U primarnom fokusu nalazi se hepatitis $B$, zato što za hepatitis $C i$ HIV nije dostupna profilaksa u obliku vakcinacije.

Hrvatsku ubrajamo u zemlje s niskom učestalošću hepatitisa B - naime, ta bolest je u opadanju posljednjih dvadesetak godina zbog cijepljenja, no i dalje je važan javnozdravstveni problem s obzirom na to da je oko 25000 osoba u Hrvatskoj kronično zaraženo tim virusom $(2,7)$.

Od 1999. cijepljenje protiv hepatitisa B uvedeno je u kalendar obveznih cijepljenja te su cijepljena djeca u dobi od 12 godina (6. razred osnovne škole). U tom razdoblju obvezno je bilo i cijepljenje svih u povećanim riziku od infekcije (npr. zdravstvenog osoblja, bolesnika na hemodijalizi, intravenskih korisnika droge, kućnih kontakata kroničnih vironoša, novorođenčadi i HBsAg pozitivnih majki). Nakon toga je u program cijepljenja, od 2007. godine, uvedeno cijepljenje novorođenčadi protiv hepatitisa B (13).

Kad je riječ o prijenosu HIV-a, ulazak Hrvatske u EU ubrzao je migraciju stanovništva. To je povećalo i opasnost od potencijalnih zaraza. $U$ rezultatima našeg istraživanja jedan ubodni incident iglom dogodio se pri radu s HIV-pozitivnim pacijentom. Stomatolog je nakon toga mjesec dana bio prisiljen na postekspozicijsku profilaksu. Rizik od prijenosa infekcije nakon perkutane ozljede stomatologa, ako je pacijent bio zaražen HIV-om, jest oko $0,3 \%$, a ne mogu se zanemariti ni moguće nuspojave postekspozicijske profilakse (12).

$\mathrm{U}$ istraživanju prijavljenih perkutanih ozljeda među zdravstvenim osobljem u Washington Stateu tijekom sedam godina, $20 \%$ prijava odnosilo se na stomatologe. Od ukupno 894 takve ozljede osam je bilo povezano s pacijentima koji su bili pozitivni na HBV, 30 s pozitivnima na $\mathrm{HCV}$, tri koji su bili pozitivni na HIV i dva na HBV i HCV (14).

Istraživanjem u Litvi bilo je obuhvaćeno 2235 općih stomatologa (15). Njih više od $95,3 \%$ izrazilo je zabrinutost zbog potencijalnog rizika da će se zaraziti od pacijenta. Kod 35,9\% stomatologa bila je zabilježena imunizacija protiv HBV-a. Kod 4,3 \% ustanovljena je infekcija hepatitisom u ranijem razdoblju, a 78,5\% doživjelo je ubodni incident iglom ili oštrim instrumentom. Statistički značajna razlika uočena je u procijepljenosti između stomatologa koji 
tion from an earlier period was reported in $4.3 \%$ of dentists. A puncture incident with a needle or sharp instrument was present in $78.5 \%$ of dentists. A statistically significant difference was found in the vaccination rate among dentists who work in urban areas, where immunization coverage is greater, compared to the rural environment.

A study conducted in Germany (16) was focused on the exposure to blood pathogens in dentists and dental students. The study confirmed that the dentist's skill plays an important role in the occurrence of potential injuries. Thus, dental students had twice as many needle injuries as dentists with work experience. $54.3 \%$ of dentists had at least one stabbing incident in their working lives. As many as $25 \%$ of dentists stated that they did not wear a protective mask, and 55.6\% said that they did not wear safety glasses while working. 50\% of respondents reported stress and loss criteria as a trigger for a stabbing incident. Fatigue was reported by $32.9 \%$ as the cause for the injury.

Injury of the eyes in dentistry may be caused by mechanical or chemical factors. In this study, $13.37 \%$ of respondents had such an injury. Mechanical injury was most often caused by pieces of amalgam and cement, while one dentist made eye contact with the blood of an infected patient (HBV and $\mathrm{HCV}$.

Zarra and Lambrianidis examined the incidence of eye injuries in endodontics specialists in Greece (6). In the fiveyear period, infections and mechanical injuries were monitored in 147 subjects. 73\% of respondents reported an injury wherein gender and years of work had no effect on injury frequency.

The study in Saudi Arabia included 233 dentists. Over $51 \%$ of respondents reported experiencing an eye incident. The risk increased with years of work and lack of education. It is also reported that $15 \%$ of dentists have never worn protective equipment (17).

Among the causes of occupational diseases and injuries at work, which were identified by the respondents as the most important risk factors in our study, the incorrect position of the body at work $(\mathrm{N}=402)$, stress $(\mathrm{N}=291)$ and infections $(\mathrm{N}=215)$ have been highlighted. Improper posture is the main cause of neck, lower back and shoulder pain, which has been confirmed by numerous studies. $(5,18,19)$ Stress, loss of concentration and fatigue have also been recognized as important role models for the emergence of a stabbing incident in the Wicker and Raubenau study, conducted in Germany (16). Infection was identified as a risk factor by 215 subjects, which supports the fact that dentists are aware of this danger but perhaps not sufficiently. It is necessary to make efforts on raising the awareness about this problem during the period of university education, but also continuously within the framework of continuing education $(20,21)$.

\section{Conclusion}

From the results of this research conducted on a representative sample of dentists in the Republic of Croatia, we can conclude that the rates of occupational injuries are disturbing. More than $63 \%$ of respondents had some type of rade u urbanoj sredini gdje je procijepljenost veća, u odnosu prema ruralnim krajevima.

$\mathrm{U}$ istraživanju provedenom u Njemačkoj (16) analizirala se izloženost stomatologa i studenata stomatologije krvnim patogenima. Potvrđeno je da je vještina stomatologa vrlo važna u nastanku potencijalnih ozljeda. Tako su studenti stomatologije imali dva puta više ozljeda iglom, negoli stomatolozi $s$ radnim iskustvom. Barem jedan ubodni incident $\mathrm{u}$ radnom vijeku navelo je 54,3\% stomatologa. Njih čak $25 \%$ izjavilo je da se ne služe zaštitnom maskom, a 55,6 \% da se ne koriste ni zaštitnim naočalama tijekom rada. Kriterij stresa i gubitka koncentracije istaknulo je kao okidač u slučaju ubodnog incidenta $50 \%$ ispitanika. Umor kao razlog za ozljedu navelo je njih 32,9\%.

Ozljedu oka u stomatološkoj djelatnosti mogu uzrokovati mehanički ili kemijski čimbenici. U ovom istraživanju navelo ju je 13,37 \% ispitanika. Najčešće je bila riječ o mehaničkoj ozljedi komadićima amalgama i cementa, a jednom stomatologu je spojnica oka došla u doticaj s krvlju zaraženog pacijenta (HBV i HCV).

Zarra i Lambrianidis ispitivali su učestalost ozljeda oka među specijalistima endodoncije u Grčkoj (6). U petogodišnjem razdoblju pratili su infekcije i mehaničke ozljede 147 ispitanika. Istaknuli su da je njih $73 \%$ prijavilo incident. Pritom spol i godine rada nisu utjecale na frekvenciju ozljeda.

Istraživanje u dijelu Saudijske Arabije obuhvatilo je 233 stomatologa. Više od $51 \%$ ispitanika navelo je kao incident ozljedu oka. Rizik se povećavao s godinama rada i zbog nedovoljne izobrazbe. Zabilježen je i podatak da se $15 \%$ stomatologa nikad nije koristilo zaštitnom opremom (17).

Među uzročnicima profesionalnih bolesti i ozljeda na radu koje su ispitanici naveli kao najvažnije rizične čimbenike, u našem istraživanju ističu se nepravilan položaj tijela pri ra$\mathrm{du}(\mathrm{N}=402)$, stres $(\mathrm{N}=291)$ te infekcije $(\mathrm{N}=215)$. Nepravilan položaj tijela pri radu glavni je uzročnik bolova u vratu, donjem dijelu leđa i ramenima, što je potvrđeno u mnogobrojnim istraživanjima $(5,18,19)$. Stres, gubitak koncentracije i umor također su navedeni kao važni čimbenici za nastanak ubodnog incidenta u istraživanju Wickera i Raubenaua provedenog Njemačkoj (16). Infekciju je, kao rizični čimbenik, navelo 215 ispitanika, što podupire stajalište da su stomatolozi svjesni te opasnosti, ali možda ne i dovoljno. Jačati svijest o tom problemu potrebno je već tijekom studija, ali i kontinuirano u sklopu trajne izobrazbe $(20,21)$.

\section{Zaključak}

Iz rezultata ovog istraživanja provedenog na reprezentativnom uzorku stomatologa u Republici Hrvatskoj, možemo zaključiti da su anketirani stručnjaci zabrinuti zbog učestalosti ozljeda na radu. Više od $63 \%$ ispitanika navelo je neku 
injury sustained while working with patients, most often a stabbing incident. The respondents were aware of the risks at their workplace and they identified the improper position of the body at work, stress, infections and noise as the most important risk factors. Knowledge of risk factors is the first step in injury prevention; hence we can conclude that our respondents were largely aware of the dangers surrounding them. Nevertheless, the occurrence of injuries was high. We may also reduce some risk factors ourselves and / or avoid their undesirable effects by careful and preventive behavior. Dentists need to be alert to do their job safely and efficiently, understand the need for on-going education and training to keep pace with demands of dental profession and design prevention programs in order to raise awareness about this issue. The risk of transmission of infections in dental work (hepatitis, HIV) dictates the need for lifelong care in terms of systemic preventive action.

Since 2014, the "Symposium on Occupational Diseases and Diseases Related to Work at Dentists" has been held regularly in Croatia, with the purpose of introducing dentists to the existing risks to their health and ways of preventive action and responsible behavior. Competition market unfortunately dictates the pace of work where, due to speed and high levels of stress, working conditions become unfavorable and the risk of injury at work increases.

Therefore, it is important to continuously educate dentists, during their study and later, enabling them to be ready to face the risk factors and behave responsibly during their activity, not to impair their own health while caring for oral health of their patients.

\section{Conflict of interest}

None declared vrstu ozljede dobivenu tijekom rada s pacijentima, a najčešće je to bio ubodni incidenti. Ispitanici su bili svjesni rizika na svojem radnom mjestu, a kao najvažniji rizični čimbenik istaknuli su nepravilan položaj tijela pri radu, stres, infekcije i buku. Najvažnije je u prevenciji ozljeda znati rizične čimbenike i zato možemo zaključiti da su naši ispitanici velikim dijelom bili svjesni opasnosti koje ih okružuju. Unatoč tomu učestalost ozljeda bila je velika. Neke rizične čimbenike možemo i sami smanjiti i/ili izbjeći njihov nepoželjni učinak pažljivim i preventivnim ponašanjem. Informiranost o tim temama, trajna edukacija i osmišljeni preventivni programi osvješćuju tu problematiku. Rizik od prijenosa infekcija u stomatološkom radu (hepatitisa, HIV-a) zahtijeva sustavno cjeloživotno preventivno djelovanje. U Hrvatskoj se od 2014. godine redovito održava simpozij o profesionalnim bolestima i bolestima vezanima uz rad stomatologa, čija je svrha obavijestiti doktore dentalne medicine o postojećim rizicima za njihovo zdravlje i načinima preventivnog djelovanja te o odgovornom ponašanju. Konkurencija na tržištu nažalost diktira tempo, pa zbog brzine i visoke razine stresa uvjeti rada postaju nepovoljni, a rizik od ozljeda veći. Zbog toga je važno stalno educirati stomatologe, već i tijekom studija, kako bi se odgovorno ponašali i bili spremni suočiti se s rizičnim čimbenicima i kako ne bi radi očuvanja oralnoga zdravlja svojih pacijenata narušili vlastito.

\section{Sukob interesa}

Autori nisu bili u sukobu interesa.
Sažetak

Za stomatološku profesiju karakterističan je, nažalost, veliki rizik od ozljeda na radu. Uzrok su specifični radni uvjeti - radno polje je malo i nalazi se u ustima pacijenta, rukuje se mnogobrojnim oštrim instrumentima i svrdlima koja se okreću velikom brzinom, što uz vodeno hlađenje stvara aerosol kontaminiranu mnoštvom čestica sline i krvi. Na taj se način na stomatologa mogu prenijeti infekcije s pacijenta zaraženog, na primjer, hepatitisom B i/ili C, ili HIV-om ako se slučajno ubode iglom ili poreže, što su najčešće ozljede stomatologa na radu, a slijede ih prema učestalosti ozljede oka. Svrha rada: Svrha ovog rada bila je istražiti učestalost ozljeda stomatologa na radu u Hrvatskoj, koje su ozljede najčešće te ustanoviti rizične čimbenike za njihov nastanak (spol, dob, specijalizacija, godine staža). Jedan od ciljeva istraživanja bio je i doznati mišljenje stomatologa o uzročnicima odgovornima za nastanak profesionalnih bolesti i ozljede na radu. Materijal i metode: Istraživanje je provedeno na uzorku od 406 stomatologa u Hrvatskoj koji su odgovorili na pitanja postavljena u elektroničkoj anketi. Rezultati: Ozljedu koja je nastala tijekom obavljanja stomatološke djelatnosti imalo je 63,05 \% ispitanika, a 16,5 \% zbog je toga potražilo pomoć liječnika. Među ozljedama su najzastupljeniji bili ubodni incidenti iglom $(57,75 \%)$ te porezotine $(20,86 \%)$, slijede ozljede oka $(13,37 \%)$, ugriz pacijenta $(4,81 \%)$ pa udarac $(1,60 \%)$. Kao najvažniji uzročnik profesionalnih bolesti i ozljeda najviše ispitanika navelo je nepravilan položaj tijela pri radu, a slijede stres, infekcija i buka. Zaključak: Poznavanje rizičnih čimbenika najvažnije je u prevenciji ozljeda, stoga možemo zaključiti da su naši ispitanici velikim dijelom bili svjesni opasnosti koje ih okružuju. Unatoč tomu učestalost ozljeda bila je velika pa su i dalje potrebne preventivne mjere kao bi se ozljede svele na najmanju moguću razinu.
Zaprimljen: 15. siječnja 2020.

Prihvaćen: 1. ožujka 2020.

Adresa za dopisivanje Ivana Savić Pavičin,

Sveučilište u Zagrebu

Stomatološki fakultet

Zavod za dentalnu antropologiju Gundulićeva 5, 10000 Zagreb, Hrvatska

savic@sfzg.hr

Ključne riječi

ozljede na radu; stomatolozi; Hrvatska; rizični čimbenici

\section{References}

1. Firić I, Krstić Vukelja E, Firić M, Mustajbegović J. Profesionalni rizici u dentalnoj medicini. Sigurnost. 2016;58(2):145-53.

2. Šarić, M; Žuškin, E - editors. Medicina rada i okoliša. Zagreb: Medicinska naklada; 2002. pp. 820.

3. Imran A, Imran H, Ashley MP. Straight to the point: considering sharp safety in dentistry. Br Dent J. 2018 Sep 14;225(5):391-394.
4. Orlovac Poplašen D, Knežević B. Ubodni incidenti kao ozljeda na radu. Sigurnost. 2012; 54(2):217-19.

5. Vodanović M, Slavica S, Galić I. Profesionalni zdravstveni problemi među stomatolozima u Hrvatskoj. Acta Stomatol Croat. 2016 Dec;50(4):310-320.

6. Zarra T, Lambrianidis T. Occupational ocular accidents amongs 
Greek endodontists:a national questionnaire survey. Int Endod J. 2014 Aug;47(8):791-801.

7. Hrvatski zavod za javno zdravstvo. Zagreb: Hrvatski zavod za javno zdravstvo; c2019.[cited 2019 Oct 25] Virusni hepatitisi;[about 7 p.]. Avilable from: https://www.hzjz.hr/aktualnosti/virusnihepatitisi/

8. Hrvatski zavod za javno zdravstvo. Zagreb: Hrvatski zavod za javno zdravstvo; c2019.[cited 2019 Oct 25] Registar za HIV;[about 3 p.]. Avialable from: https://www.hzjz.hr/sluzba-epidemiologija-zarazne-bolesti/registar-za-hiv/

9. Hrvatska komora dentalne medicine. Zagreb: Hrvatska komora dentalne medicine; 2018. Strategija razvoja dentalne medicine 2017- 2025; 2018. [cited 302019 Oct 30]. Available from: http:// www.hkdm.hr/pic_news/files/pdf/2019/strategija-dent-medicine-2017-2025.pdf

10. Al-Zoughool M, Al-Shehri Z. Injury and infection in dental clinics: Risk factors and prevention. Toxicol Ind Health. Toxicol Ind Health. 2018 Sep;34(9):609-619.

11. Hrvatski zavod za zaštitu zdravlja i sigurnost na radu. Analiza ozljeda oštrim predmetima. Zagreb: Hrvatski zavod za zaštitu zdravlja i sigurnost na radu. 2019 [cited 2019 Nov 07]. Available from: http://hzzzsr.hr/wp-content/uploads/2019/04/Analizaubodni.pdf

12. Čivljak R. Profesionalna izloženost stomatologa infekcijama koje se prenose krvlju. U: Vodanović M, ur. Profesionalne bolesti i bolesti vezane uz rad stomatologa. Jastrebarsko: Naklada Slap, 2015.

13. Hrvatski zavod za javno zdravstvo. Zagreb: Hrvatski zavod za javno zdravstvo; c2019.[cited 2019 Oct 25]. Kalendar kontinu- iranog cijepljenja u Republici Hrvatskoj u 2019. godini; [about 4 p.]. Available from: https://javno-zdravlje.hr/kalendar-kontinuiranog-cijepljenja-u-republici-hrvatskoj-u-2019-godini/

14. Shah SM, Merchant AT, Dosman JA. Percutaneous injuries among dental professionals in Washington State. BMC Public Health. 2006 Oct 30;6:269.

15. Rimkuviene J, Puriene A, Peciuliene V, Zaleckas L. Percutaneous injuries and hepatitis $B$ vaccination among Lithuanian dentists. Stomatologija. 2011;13(1):2-7.

16. Wicker S, Rabenau HF. Occupational exposures to bloodborne viruses among German dental professionals and students in a clinical setting. Int Arch Occup Environ Health. 2010 Jan;83(1):77-83.

17. Alsabaani NA, Awadalla NJ, Abu Saq IH, Abualiat ZM, Alshahrani MA, Alqahtani AM, Alshuraym MM. Occupational ocular incidents in dentists: a multicentre study in southwestern Saudi Arabia. Int Dent J. 2017 Dec;67(6):371-377.

18. Ayers KM, Thomson WM, Newton JT, Morgaine KC, Rich AM. Selfreported occupational health of general dental practitioners. Occup Med (Lond). 2009 May;59(3):142-8.

19. Puriene A, Aleksejuniene J, Petrauskiene J, Balciuniene I, Janulyte V. Self-reported occupational health issues among Lithuanian dentists. Ind Health. 2008 Aug;46(4):369-74.

20. Matoš K, Jurec Z, Galić I, Vodanović M. Izobrazba o profesionalnim bolestima i zdravstvenim navikama među studentima dentalne medicine u Hrvatskoj. Acta Stomatol Croat. 2016 Mar;50(1):4957.

21. Moodley R, Naidoo S, Wyk JV. The prevalence of occupational health-related problems in dentistry: A review of the literature. I Occup Health. 2018 Mar 27;60(2):111-125. 